\title{
Influence of Organic Amendments on Soil Fertility and the Growth of Maize (Zea Mays)
}

\author{
Meshack Appiah Ofori ${ }^{1}$, Isaac Eminent ${ }^{2}$, Isaac Sarfo ${ }^{3}$, Collins Oduro ${ }^{3}$ \\ ${ }^{1}$ College of Biology and the Environment, Nanjing Forestry University, Nanjing 2010037, PR China \\ ${ }^{2}$ Department of Environmental Management, University of Energy and Resource, Sunyani 214, Ghana \\ ${ }^{3}$ Research Institute for History of Science and Technology, Nanjing University of Information Science and \\ Technology, Nanjing 210044, PR China
}

\begin{abstract}
In recent years, the application of poultry manure and compost as a soil amendment has generated huge interest for the preservation of soil fertility by improving the physicochemical and biological properties of soil, and for the reduction of the negative effects of greenhouse emissions. This study, investigated the effect of two soil amendments, namely poultry manure and compost, on soil parameters and their influence on maize growth performance. The experiment was conducted at the nursery site at the University of Energy and Natural Resources where organic amendments were applied to the soil at different application rate compost (10 t/ha and $5 \mathrm{t} / \mathrm{h}$ ) and poultry (10 t/ha and $5 \mathrm{t} / \mathrm{h}$, respectively). The results show that organic amendments increased the NPK content of the soil. Plant growth parameters are also increased by the application of the organic amendment. There was no significant improvement in plant height, plant girth, and the number of leaves with the application of both poultry manure and compost. However, biomass yield and leaf area of plants significantly increased in soils amended with poultry manure and compost. Poultry manure was found to contain higher nutrients and contributed to higher maize growth than compost and the control. This study showed that organic amendments increased soil fertility and crop growth.
\end{abstract}

Keyword: Soil fertility, Organic fertilizers, Poultry Manure, Compost.

\section{INTRODUCTION}

Smallholder farming is a common livelihood activity sustaining food production in Ghana (Okoh \& Hilson, 2011). These farms have depended on traditional practices such as shifting cultivation, slash and burn as means for sustaining the soil fertility of such farms. However, with increasing urbanization and human population, farmers are forced to practice continuous and intensive food production on the same piece of land without adequately replenishing the soils. This has resulted in the rapid depletion of nutrients in these farms (Mokwunye et al., 1996). These farmers are not able to secure the needed resources to invest in soil fertility inputs, particularly mineral fertilizers, resulting in low food production (Badiane \& Delgado, 1995), which poses a serious threat to food security in the country.

The use of organic amendments has emerged as a cheap alternative to the expensive fertilizer applications, for improving soil fertility and food production (Calderón et al., 2005). Organic amendments emanate from a variety of sources which constitute agriculture, forestry, and industrial sources. However, those generated from farm materials like livestock manure is most prevalent (Larney \& Angers, 2012). Organic amendments can provide nutrients for plant growth, and supply organic materials for soil improvement.

Continuous and intensive farming may result in the depletion of soil fertility. Particularly, small-scale farmers cannot afford the cost of purchasing inorganic fertilizers as a substituent for the soil's nutrient deficiency. In the event of applying inorganic fertilizers, soil salinity increases, thereby making the soil poor due to poor microbial activity. The search for fertile land for the cultivation of crops has increased the clearing of forest reserves in the country (Appiah et al., 2009). Limited attention has been given to the use of organic amendments in smallholder farms as an alternative to inorganic fertilizers in improving soil fertility in Ghana. 
Poor soils are expensive to reclaim because of the high cost of chemical fertilizers. Also, the application of inorganic fertilizers ends up increasing soil acidity and hardening of the soil to render it unproductive (Lai et al., 1992; Blake et al., 1999). Organic amendments serve as a natural and environmentally friendly way of improving the soil properties which also enhance crop growth. Organic amendments such as compost, poultry manure, farmyard manure, and others create enabling conditions for microbial activities which in turn improve the soil's physical, chemical, and biological structure (Li \& Zhang, 2007). Although organic fertilizers contain small amounts of nutrients as compared to inorganic fertilizers, the presence of growth-promoting principles like enzymes and hormones. Besides, plant nutrients facilitate the process of enhancing soil fertility and productivity (Bhuma, 2007). The examination of the influence of organic amendments as studied would influence policy and management decisions on the use of organic amendments as cheap, environmentally friendly, and effective farm input in smallholder farming systems to increase food production. This study sought to investigate the effects of organic amendments on soil fertility and the growth performance of maize. It further sought to determine the effects of organic amendments on soil chemical properties, as well as examining the effects of organic amendments on maize growth performance.

\section{MATERIALS AND METHOD}

\subsection{Experimental and material description}

A pit of $1 \mathrm{~m}$ x 1m was dug at the nursery site of the University of Energy and Natural Resources. The compost contained layers of household waste, dry plant material, wood ashes, topsoil, cow dung, and sawdust. Water is important for all enzymatic processes, so the water was sprinkled over several layers each time the soil was turned. The topsoil served as an inoculum, depicting the main source of microorganisms for the compost. The compost was protected from the sun by a shade to prevent high rate of evaporation, overheating, and drying out. The compost was turned in every two weeks. The temperature and biological activity were monitored by pushing a stick into the middle of the pit. The stick was pulled out each time the compost was turned, and felt by hand for temperature changes. Turning was important as it ensures aeration, wetting, proper mixing, and decomposition. After two months, the compost was sieved and ready to be used on the field.

Poultry manure was collected from a poultry farm at Fiapre. The decomposed poultry manure was mixed with soil and used to fill the poly pots at $10 \mathrm{t} / \mathrm{ha}$ and 5t/ha, a week before sowing. Compost (10 t/ha and $5 \mathrm{t} / \mathrm{h}$ ) was also incorporated into the soil in their respective poly pots before sowing.

\subsection{Soil Sampling and Organic Amendments Analysis}

Before planting, a representative soil sample used in filling the poly pots was taken at different parts of the field. Soil samples were randomly selected at each block and the samples were taken at a depth of $0-15 \mathrm{~cm}$. They were then mixed thoroughly, airdried, grounded and the soil samples were passed through a $2.0 \mathrm{~mm}$ (20 mesh) sieve to remove roots before laboratory analyses.

In setting up the experiment, soil sample, compost, and poultry manure were analyzed at Soil Research Institute at Kwadaso, Kumasi, for initial analysis of macronutrients (Nitrogen, Phosphorus, Potassium) concentration, as well as soil organic carbon and $\mathrm{pH}$. The $\mathrm{pH}$ was determined using an Orion Ionalyzer Model $901 \mathrm{pH}$ meter in a 1: 2.5, whilst organic carbon was determined by Walkley-Black wet oxidation method (Nelson \& Sommers, 1982). Total nitrogen was determined by the micro-Kjeldahl distillation technique as described by (Breminer \& Mulvaney, 1982). Available phosphorus was determined by Bray No. 1 method (IITA, 1979). Exchangeable potassium was determined by spectrophotometer by using the Olsen method.

Poultry manure, compost, and the soil were initially characterized as their nutrient composition was determined before application. The results are as follows:

Table 1: Initial soil properties before the experiment

\begin{tabular}{cc}
\hline Nutrients & Values \\
\hline Organic carbon \% & 0.72 \\
Total Nitrogen \% & 0.11 \\
Exchangeable Potassium (ppmK) & 136.67 \\
Available phosphorus (ppmP) & 12.2 \\
$\mathrm{pH}$ & 7.24 \\
\hline
\end{tabular}


Table 21: Initial analysis of the compost used for the experiment

\begin{tabular}{cc}
\hline Nutrient & Values \\
\hline Organic carbon \% & 4.29 \\
Total Nitrogen \% & 0.31 \\
Exchangeable Potassium (ppmK) & 434.43 \\
Available phosphorus (ppmP) & 1.36 \\
$\mathrm{pH}$ & 7.54 \\
\hline
\end{tabular}

Table 3: Initial analysis of the poultry manure used for the experiment

\begin{tabular}{ccc}
\hline Nutrients & Percentages (\%) & Ph \\
Nitrogen & 2.13 & 7.67 \\
Phosphorus & 0.74 \\
Potassium & 0.52 \\
Organic carbon & 18.5 \\
\hline
\end{tabular}

\subsection{Experimental Design}

The field experiment was carried out at the nursery site of the University of Energy and Natural Resources. A land area measuring $14 \mathrm{x}$ $7 \mathrm{~m}^{2}$ was cleared prepared and marked out, the design employed in this study was randomized complete block design (RCBD) with three replicates and five treatments as follows:

1) Control - no addition of compost or poultry manure

2) COMP 10 - 10 tons of compost per hectare

3) COMP 5 - 5 tons of compost per hectare

4) POM 10- 10 tons of poultry manure per hectare

5) POM 5- 5 tons of poultry manure per hectare 


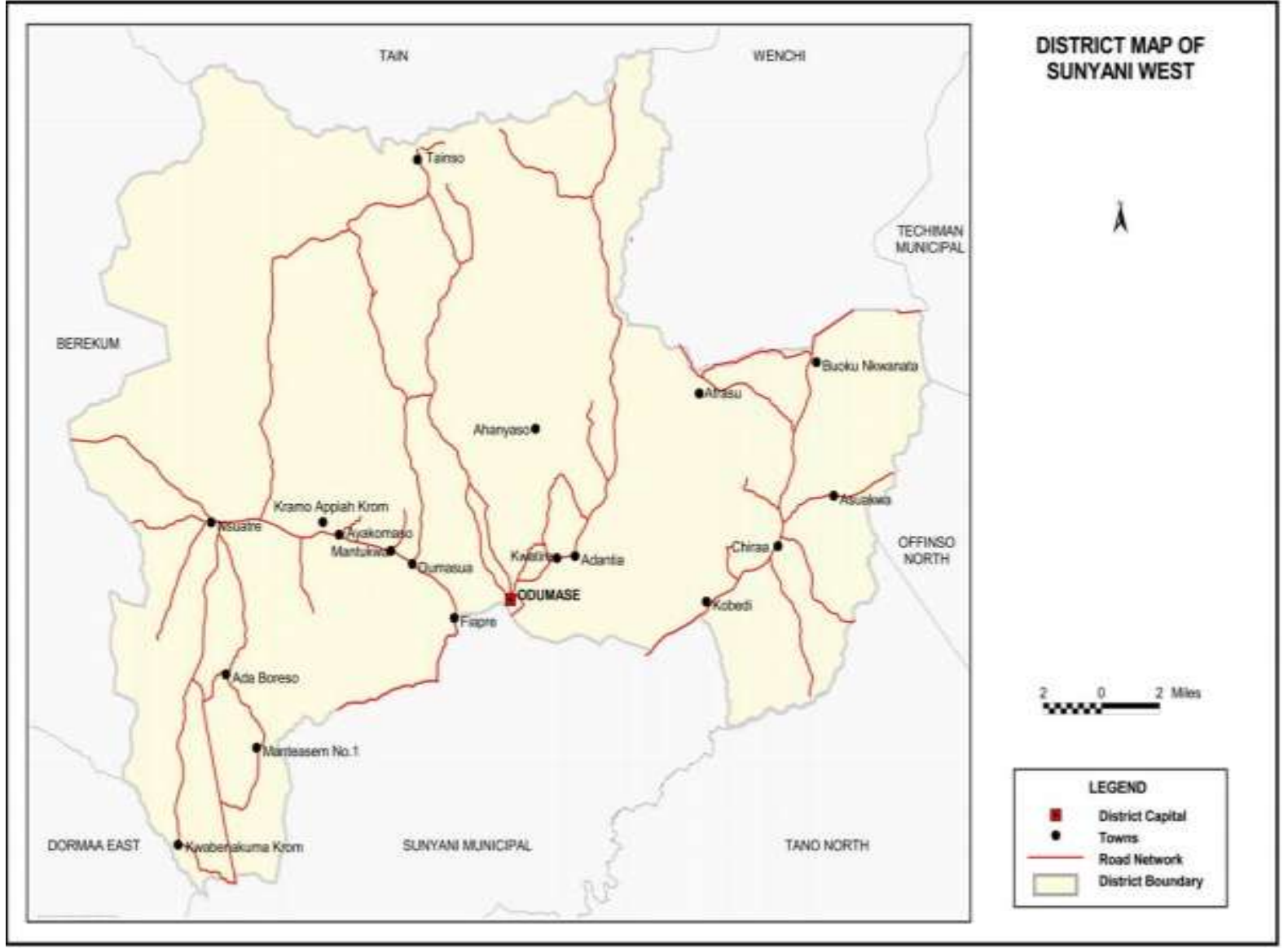

Fig 1: Geographical location of the study area

Each block had a total surface area of $4.5 \mathrm{~m}^{2}$. Also, five treatments are repeated five times within each block. Each subplot has an area of $0.063 \mathrm{~m}^{2}$. Between the blocks, a space of one meter was left vacant. The subplots were arranged five rows per block with five poly pots on each row at $60 \mathrm{~cm} \times 30 \mathrm{~cm}$ (Table 2).

Table 4: Shows how the area was blocked.

BLOCK A

\begin{tabular}{|l|}
\hline 10 t COMP/ha \\
\hline 5 t POM/ha \\
\hline Control \\
\hline 5 COMP/ha \\
\hline 10 t POM/ha \\
\hline
\end{tabular}

BLOCK B

\begin{tabular}{|l|}
\hline $5 \mathrm{t} \mathrm{COMP} / \mathrm{ha}$ \\
\hline $10 \mathrm{t} \mathrm{POM} / \mathrm{ha}$ \\
\hline $10 \mathrm{t} \mathrm{COMP} / \mathrm{ha}$ \\
\hline $5 \mathrm{t} \mathrm{POM} / \mathrm{ha}$ \\
\hline Control \\
\hline
\end{tabular}

BLOCK C

\begin{tabular}{|l|}
\hline 10 t POM/ha \\
\hline Control \\
\hline 5 t COMP/ha \\
\hline 10 t COMP/ha \\
\hline 5 t POM/ha \\
\end{tabular}

Poultry manure was collected from a poultry farm at Fiapre. The decomposed poultry manure was mixed with soil and used to fill the poly pots at $10 \mathrm{t} / \mathrm{ha}$ and $5 \mathrm{t} / \mathrm{ha}$, a week before sowing. Compost (10 t/ha and $5 \mathrm{t} / \mathrm{h}$ ) was also incorporated into the soil in the respective poly pots before sowing.

In this study, the seeds variety used were the commercial maize hybrid (Belgrano, Limagrain, FAO 300). Crop sowing was at a rate of two seeds per pot. The crop was thinned to one plant per pot whilst at the $3^{\text {rd }}$ leaf stage, water was applied to all pots during the crop growing season, aiming to meet the water requirements of the crop. The same amount of water was applied to all pots. 


\subsection{Plant sampling and Analysis}

The different maize phenological development stage was monitored, growing non-destructive parameters (i.e., plant height, number of leaves, leaf girth, length, and width) were determined eight weeks after germination. Biomass assessment was made 90 after the emergences. Five plants were randomly uprooted and oven-dried at $70^{\circ} \mathrm{C}$ to constant weight for both root and shoot biomass.

\subsection{Statistical Analysis}

Data obtained on plant height, girth, number of leaves, leaf area, dry matter composition, and nutrients status were analyzed using oneway analysis of variance (ANOVA) at a 5\% level of significance using Minitab Statistical Software (version 17). Fisher's comparison test was used to separate treatment means where there was a significant difference.

\section{RESULTS}

\subsection{Soil Assessment Before and After the Study}

There was a general increase in NPK for compost (10 and 5 tons/ha) and poultry manure (10 and 5 tons/ha) after the application of the organic amendments. Poultry manure recorded the highest whilst the control recorded the lowest. However, there was an observed reduction in the nutrient's status after the studies.

Table 5: Soil nutrient assessment before and after the study in different organic amendments techniques using compost and poultry manure

\begin{tabular}{|c|c|c|c|c|c|c|}
\hline \multirow[b]{2}{*}{ Treatments (t/ha) } & \multicolumn{2}{|c|}{$\%$ Nitrogen } & \multicolumn{2}{|c|}{ Bray-1 Phosphorus (ppm) } & \multicolumn{2}{|c|}{ Bray-1 Potassium (ppm) } \\
\hline & Initial & Final & Initial & Final & Initial & Final \\
\hline COMP 10 & 0.42 & 0.21 & 13.56 & 7.73 & 434.43 & 410.82 \\
\hline COMP 5 & 0.40 & 0.20 & 13.2 & 6.7 & 412.39 & 392.11 \\
\hline POM 10 & 2.24 & 1.13 & 7400 & 7387.20 & 5200 & 5187.84 \\
\hline POM 5 & 2.06 & 1.23 & 7348 & 7337.70 & 5162 & 5135.02 \\
\hline Control & 0.11 & 0.06 & 12.2 & 6.42 & 136.67 & 117.67 \\
\hline
\end{tabular}

\subsection{Height Growth of Maize Responses to organic amendments}

Results from one-way analysis of variance at a $5 \%$ level of significance show no significant difference $(p>0.05)$ between the treatments (Table 5). Generally, higher heights growth of maize was recorded in soils amended with poultry manure. Comparable mean heights of $24.95 \pm 4.11$ and $23.50 \pm 3.94$ growth of maize were found in the poultry manure of 10 and 5 tons/ha, respectively. Moreover, soil amended with compost quantities of 10 and 5 tons/ha recorded mean heights of maize of $19.76 \pm 2.98$ and $20.20 \pm 2.97$, respectively. The control recorded the lowest mean height $(16.87 \pm 1.94)$ of maize.

Table 6: Effects of organic amendments on height growth of Maize

\begin{tabular}{ccccc}
\hline Treatments $(\mathrm{t} / \mathrm{ha})$ & Means \pm Standard Error $(\mathrm{cm})$ & $\begin{array}{c}\text { Coefficient of } \\
\text { variation }\end{array}$ & \multicolumn{2}{c}{ Range } \\
\cline { 4 - 5 } COMP 10 & $19.76 \pm 2.98$ & 42.63 & Maximum & Minimum \\
COMP 5 & $(\mathrm{A})$ & & 34.80 & 11.60 \\
POM 10 & $20.20 \pm 2.97$ & 41.55 & 36.00 & 11.20 \\
POM 5 & $24.95 \pm 4.11$ & & 43.62 & 11.80 \\
$(\mathrm{~A})$ & 46.62 & & 11.40
\end{tabular}


International Journal of Research in Agriculture, Biology \& Environment (ijagri), Vol. 2 (3), Jul-Sep - 2021

(A)

\begin{tabular}{|c|c|c|c|c|}
\hline Control & $\begin{array}{c}16.87 \pm 1.94 \\
(\mathrm{~A})\end{array}$ & 32.55 & 26.44 & 11.20 \\
\hline D.F & 4 & & & \\
\hline P-value & 0.445 & & & \\
\hline
\end{tabular}

*Means that do not share a similar letter are significantly different at a 5\% significance level.

\subsection{Effects of Organic Amendments on the Number of Leaves of Maize}

Results from one-way analysis of variance at a $5 \%$ level of significance revealed no significant difference $(p>0.05)$ between the treatments (Table 6). Generally, a higher number of leaves of maize was recorded in soil amended with poultry manure. Comparable but the highest mean number of leaves of $7.38 \pm 1.15$ and $7.25 \pm 0.99$ growth of maize was found in the poultry manure of 10 and 5 tons/ha respectively. Moreover, soil amended with compost quantities of 10 and 5 tons/ha recorded the mean number of leaves of maize of $6.50 \pm 0.87$ and $6.75 \pm 0.99$, respectively. The control recorded the mean number of leaves $(6.50 \pm$ $0.87)$ of maize.

Table 7: Effects of organic amendments on the number of leaves of Maize

\begin{tabular}{|c|c|c|c|c|}
\hline \multirow[t]{2}{*}{ Treatments (t/ha) } & \multirow[t]{2}{*}{ Means \pm Standard Error } & \multirow{2}{*}{$\begin{array}{c}\text { Coefficient of } \\
\text { variation }\end{array}$} & \multicolumn{2}{|c|}{ Range } \\
\hline & & & Maximum & Minimum \\
\hline COMP 10 & $\begin{array}{c}6.50 \pm 0.87 \\
(\mathrm{~A})\end{array}$ & 37.68 & 10.00 & 3.00 \\
\hline COMP 5 & $\begin{array}{c}6.75 \pm 0.99 \\
(\mathrm{~A})\end{array}$ & 41.72 & 11.00 & 3.00 \\
\hline POM 10 & $\begin{array}{c}7.38 \pm 1.15 \\
\text { (A) }\end{array}$ & 44.05 & 12.00 & 3.00 \\
\hline POM 5 & $\begin{array}{c}7.25 \pm 0.99 \\
(\mathrm{~A})\end{array}$ & 38.84 & 11.00 & 3.00 \\
\hline Control & $\begin{array}{c}6.50 \pm 0.87 \\
(\mathrm{~A})\end{array}$ & 37.68 & 10.00 & 3.00 \\
\hline D.F & 4 & & & \\
\hline P-value & 0.948 & & & \\
\hline
\end{tabular}

\subsection{Effects of organic Amendments on Girth Growth of Maize}

Girth growth of maize in different organic amendments with compost and poultry manure was not significantly different (p > 0.05 ) at a 5\% significance level. Generally, higher girths of maize were recorded in soil amended with poultry manure. Higher mean girths of $3.22 \pm 0.51$ and $3.09 \pm 0.47$ were found in poultry manure with quantities 10 and 5 tons per hectare, respectively. Also, comparable mean girths were recorded for composts 10 tons/ha $(2.46 \pm 0.34)$ and 5 tons/ha $(2.57 \pm 0.38)$. The control recorded the lowest mean girth $(2.23 \pm 0.24)$ of maize as shown in Table 7 .

Table 8: Effects of organic amendments on girth growth of maize

\begin{tabular}{|c|c|c|c|c|}
\hline \multirow[t]{2}{*}{ Treatments (t/ha) } & \multirow[t]{2}{*}{ Means \pm Standard Error $(\mathrm{cm})$} & \multirow{2}{*}{$\begin{array}{l}\text { Coefficient of } \\
\text { variation }\end{array}$} & \multicolumn{2}{|c|}{ Range } \\
\hline & & & Maximum & Minimum \\
\hline COMP 10 & $\begin{array}{c}2.46 \pm 0.34 \\
\text { (A) }\end{array}$ & 39.00 & 3.82 & 1.10 \\
\hline COMP 5 & $\begin{array}{c}2.57 \pm 0.38 \\
(\mathrm{~A})\end{array}$ & 42.15 & 4.00 & 1.00 \\
\hline POM 10 & $\begin{array}{c}3.22 \pm 0.51 \\
\text { (A) }\end{array}$ & 45.09 & 5.21 & 1.20 \\
\hline POM 5 & $\begin{array}{c}3.09 \pm 0.47 \\
(\mathrm{~A})\end{array}$ & 42.88 & 5.08 & 1.20 \\
\hline Control & $\begin{array}{c}2.23 \pm 0.24 \\
(\mathrm{~A})\end{array}$ & 36.08 & 3.40 & 1.14 \\
\hline D.F & 4 & & & \\
\hline P-value & 0.381 & & & \\
\hline
\end{tabular}

\footnotetext{
*Means that do not share a similar letter are significantly different at a $5 \%$ significance level.
} 


\subsection{Effects of organic Amendments on the Leaf Area of Maize}

Test results from one-way analysis of variance on leaf area of maize growth in different soil amendments were statistically significant $(\mathrm{p}<0.05)$ at a 5\% significance level (Table 8). Generally, a higher leaf area of maize growth was recorded in soil amended with poultry manure. The Fisher's Comparison Test revealed significantly higher mean leaf area $(126.90 \pm 29.30)$ of maize growth in poultry manure of quantity 10tons/ha. However, comparable mean leaf area was recorded for poultry manure 5tons/ha $(116.60 \pm 26.30)$, compost 10 tons/ha $(84.20 \pm 20.70)$ and compost 5 tons/ha $(81.80 \pm 20.10)$. The control recorded a significantly lower mean area of maize growth $(59.20 \pm 12.80)$.

Table 9: Effects of organic amendments on the Leaf Area of Maize

\begin{tabular}{|c|c|c|c|c|}
\hline \multirow[t]{2}{*}{ Treatments (t/ha) } & \multirow{2}{*}{ Means \pm Standard Error $\left(\mathrm{cm}^{2}\right)$} & \multirow{2}{*}{$\begin{array}{l}\text { Coefficient of } \\
\text { variation }\end{array}$} & \multicolumn{2}{|c|}{ Range } \\
\hline & & & Maximum & Minimum \\
\hline COMP 10 & $\begin{array}{c}84.20 \pm 20.70 \\
(\mathrm{AB})\end{array}$ & 69.63 & 179.60 & 17.40 \\
\hline COMP 5 & $\begin{array}{c}81.80 \pm 20.10 \\
(\mathrm{AB})\end{array}$ & 69.49 & 180.90 & 18.10 \\
\hline POM 10 & $\begin{array}{c}126.90 \pm 29.30 \\
(\mathrm{~A})\end{array}$ & 65.35 & 253.40 & 18.90 \\
\hline POM 5 & $\begin{array}{c}116.60 \pm 26.30 \\
(\mathrm{AB})\end{array}$ & 63.78 & 230.40 & 18.60 \\
\hline Control & $\begin{array}{c}59.20 \pm 12.80 \\
\text { (B) }\end{array}$ & 61.25 & 122.60 & 17.30 \\
\hline D.F & 4 & & & \\
\hline P-value & 0.040 & & & \\
\hline
\end{tabular}

\subsection{Effects of Organic Amendments on Dry Matter Production (Biomass) of Maize}

Results from one-way analysis of variance on dry matter production of maize growth in different organic amendments were statistically significant $(\mathrm{p}<0.05)$ at a $5 \%$ significance level (Table 9). Generally, higher biomass production of maize was recorded in soils amended with poultry manure. The Fisher's Comparison Test revealed significantly higher biomass $(47.62 \pm$ 0.10 ) of maize growth in poultry manure of quantity 5 tons/ha. The biomass recorded in poultry manure 10 tons/ha was $43.37 \pm$ 0.11 , compost 10 tons/ha $(33.43 \pm 0.03)$ and compost 5 tons/ha $(33.09 \pm 0.05)$. The control recorded significantly lower dry matter production of maize $(23.80 \pm 0.01)$

Table 10: Effects of organic amendments on biomass production of Maize

\begin{tabular}{|c|c|c|c|c|}
\hline \multirow[t]{2}{*}{ Treatments (t/ha) } & \multirow[t]{2}{*}{ Means \pm Standard Error $(\%)$} & \multirow{2}{*}{$\begin{array}{c}\text { Coefficient of } \\
\text { variation }\end{array}$} & \multicolumn{2}{|c|}{ Range } \\
\hline & & & Maximum & Minimum \\
\hline COMP 10 & $\begin{array}{c}33.43 \pm 0.03 \\
(\mathrm{C})\end{array}$ & 0.02 & 33.43 & 33.42 \\
\hline COMP 5 & $\begin{array}{c}33.09 \pm 0.05 \\
\text { (D) }\end{array}$ & 0.04 & 33.10 & 33.09 \\
\hline POM 10 & $\begin{array}{c}43.37 \pm 0.11 \\
\text { (B) }\end{array}$ & 0.50 & 43.39 & 43.35 \\
\hline POM 5 & $\begin{array}{c}47.62 \pm 0.10 \\
(\mathrm{~A})\end{array}$ & 0.20 & 47.63 & 48.61 \\
\hline Control & $\begin{array}{c}23.80 \pm 0.01 \\
(\mathrm{E})\end{array}$ & 0.06 & 23.81 & 23.78 \\
\hline D.F & 4 & & & \\
\hline $\mathrm{P}$-value & 0.000 & & & \\
\hline
\end{tabular}

*Means that do not share similar letters are significantly different at a 5\% significance level. 


\section{DISCUSSION}

\subsection{Soil Analysis Before and After the Study}

The application of organic amendments increased the nutrients status of the soil (Table 5). Comparing the NPK levels in the various organic amendments, poultry manure was richer in nutrients than compost. The nutrients status of the soil increased with the increasing application rate of the organic amendments (PM10>PM5>COMP10>COMP5> CONTROL). Studies indicate that nutrients especially nitrogen content in organically amended soils are higher than soils receiving inorganic fertilization (Khatik \& Dikshit, 2001; Sullivan et al., 2003; Rodriguez et al., 2005). There was also a general reduction in the nutrient's status for the amended soils, as well as the control in the aftermath of the studies. Soils amended with poultry manure recorded the highest in nitrogen reduction $(2.24 \%$ to $1.13 \%)$, followed by compost $(0.42 \%$ to $0.21 \%)$ and the control recorded the lowest (0.11 to 0.06$)$, the same was recorded for $\mathrm{P}$ and $\mathrm{K}$. This was mainly because the nutrients in the organic amendments was readily available for plants uptake or as a result of leaching.

\subsection{Amendment influence on Maize Growth}

\subsubsection{Effects of Organic Amendments on the Height of Maize}

There was no significant difference in plant height among the treatments at the end of 8 weeks after emergence (WAE), but the maize plants that received poultry manure grew faster than those that received compost as the control recorded the lowest. Plant's height increased as the amount of poultry manure application increased. This is because the poultry manure released sufficient nutrients for the growth of maize as compared to the compost and the control. John et al., (2004) reported that poultry manure contains essential nutrient elements associated with high photosynthetic activities; hence, promotes roots and vegetative growth. The result, however, is comparable with that of Sobulo and Babalola (1992), who noticed that maize plant height from unamended soils was comparable with those amended with organic fertilizers. This suggests that poultry manure and compost seemed not to have any significant effect on the maize plant's height.

\subsubsection{Effects of Organic Amendments on the Number of Leaves}

There was no significant difference $(\mathrm{p}>0.05)$ between the treatments (Table 7). Generally, the maize plants on organically amended soils had more leaves but comparably, soils amended with poultry manure recorded the highest number of leaves of maize and the lowest was recorded in the control. This could be due to the high amount of nutrients present in poultry manure which was readily available for plant use compared to compost and the control. This is in agreement with John et al. (2004), who reported that poultry manure contains essential nutrient elements associated with high photosynthetic activities; thus, promotes roots and vegetative growth. Although there were no significant differences among the treatments, poultry manure application recorded the highest number of leaves of maize.

\subsubsection{Effects of Organic Amendments on the Girth Growth of Maize}

The girth growth of maize in different soil amendments with compost and poultry manure was not significant ( $p>0.05)$ at a $5 \%$ significance level. This could be as a result of the slow release of nutrients by organic amendments. According to Wong (2003) and Chiu et al., (2006), organic amendments provide slow release of nutrient sources such as N, P, K to help in plant growth. This means the use of organic amendments can improve plant growth over a long period. Although there was no significant difference among the treatments, higher maize girth was observed in soils with the organic amendments. Generally, there was higher maize girth in soils amended with poultry manure and compost. However, the control recorded the lowest mean girth of maize ( $\mathrm{POM}>\mathrm{COMP}>$ Control) as shown in (Table 8$)$.

\subsubsection{Effects of Organic Amendments on the Leaf area of Maize}

The leaf area increased significantly with poultry manure and compost application. This indicates that organic amendments were able to release sufficient nutrients that increased the vegetative growth of the maize. This finding is consistent with the findings of Aliyu (2000), who asserted poultry manure has a profound effect on the vegetative development of crops and ensures healthy and vigorous growth of crops. The increase in leaf area was significantly higher in soils amended with compost and poultry manure than that of the control. This observation may be attributed to the availability of nutrients in the amended soil, as well as improvement in soil properties which in turn improved upon the leaf area of the maize. According to Dauda et al., (2008), organic amendments, specifically poultry manure, promote vigorous growth, and increases physiological activities in the plant due to the supply of plant nutrients and the improvement in soil properties. We concluded that increase in the amount of poultry manure application results in increased vegetative growth as reported by Dauda et al., (2005b). Conversely, contrary observation was made with the compost.

\subsubsection{Effects of Organic Amendments on Biomass Yield}

Indications from Table 9, shows that amended soils produced significantly higher biomass than control soil. This may be due to the nutritional composition of the poultry manure and compost especially nitrogen which was converted into greater vegetative growth of the plant. Nitrogen is a component of chlorophyll and if available, chlorophyll formation will be enhanced leading to increased biomass. Biomass yield of maize generally increased significantly under the two organic amendments with poultry 
manure recording the highest biomass yield. Biomass yield increased with increasing application rate in compost (COMP $10>$ COMP 5). Consequently, it was observed from Table 9 that the POM application rate of $5 \mathrm{t} \mathrm{ha}^{-1}$ was more effective in producing biomass yield compared to $10 \mathrm{t} \mathrm{ha}^{-1}$. These results support the findings of Boateng et al. (2007), who revealed yields (biomass and grain) increased linearly up to $4 \mathrm{tha}^{-1}$ level of POM application. They further revealed higher applications 6 and $8 \mathrm{t} \mathrm{POM} \mathrm{ha-1}$ produced lower maize yields, a probable case of diminishing returns. Haruna (2011) also observed similar trends that by increasing the rate of manure from 5 to 10 and $15 \mathrm{t}$ ha-1, there was a resultant significant reduction in yield.

\section{CONCLUSIONS}

\section{Conclusions}

Organic amendments have high nutrient content and improved the chemical properties (NPK) of the soil, as compared to the control. The nutrient content in the organic amendments ranged from $2.06-2.24 \% \mathrm{~N}, 7348-7400$ ppmP; $5162-5200 \mathrm{ppmK}$ for poultry manure, $0.40-0.42 \% \mathrm{~N}, 13.20-13.56 \mathrm{ppmP}$, and $412.39-434.43 \mathrm{ppmK}$ for compost, whilst the control recorded 0.11 $\% \mathrm{~N}, 12.2 \mathrm{ppmP}$ and $136 \mathrm{ppmK}$, respectively. The results obtained from the experiment showed that there was no significant difference in these plants' parameters, thus, plant height, number of leaves, and plant girth measured among all the treatments. Contrarily, the use of organic amendments contributed significantly to biomass yield and leaf area growth of maize. Comparatively, among the organic amendments used, poultry manure contributed to higher maize growth than the compost.

Author's contributions

Meshack Appiah Ofori: Conceptualization; Supervision; Writing-original draft; Isaac Eminent: Data curation; Investigation; Isaac Sarfo: Data curation; Formal analysis; review \& editing; Collins Oduro: Data curation; Writing-review \& editing.

\section{REFERENCES}

Aliyu, L. (2000). The effects of organic and mineral fertilizer on growth, yield, and composition of pepper (Capsicum annum). Biol. Agric. Hort. 18, 29-36.

Appiah, M., Blay, D., Damnyag, L., Dwomoh, F. K., Pappinen, A. \&Luukkanen, O. (2009). Dependence on forest resources and tropical deforestation in Ghana. Environ. Dev. Sustain., 11, 471-487.

Badiane, O. \& Delgado, C. L. (1995). A 2020 vision for food, agriculture, and the environment. Washington DC: International Food Policy Research Institute.

Bhuma, M. (2007). Studies on the impact of humic acid on the sustenance of soil fertility and productivity of green gram (Unpublished master's dissertation). Tamil Nadu Agricultural University: India.

Blake, L. Goulding K.W.T., Mott, C.J. B. \&Johnston, A.E. (1999). Changes in soil chemistry accompanying acidification over more than 100 years under woodland and grass at Rothamsted Experimental Station, UK. European Journal of Soil Science, 50, 401-412.

Boateng, S.A., Kornahrens, M. \& Zickermann.J. (2007). Nitrogen use efficiency of poultry manure by maize. Journal of Science and Technology, 27 (2), 73-81.

Bremner, J.M. and Mulvancy, C.S. (1982). Nitrogen-Total. In: Page, Methods of soil analysis Part 2, Agron Monogr. 9 (2nd edition) ASA and SSSA, Madison, Wsc, pp. 403-430.

Calderón, F. J., McCarty, G. W. \& Reeves, J. B. (2005). Analysis of manure and soil nitrogen mineralization during incubation. Biol. Fert. Soils, 41, 328-336.

Chiu, K. K., Z. H. Ye, \& Wong, M. H. (2006.). Growth of Vetiveriazizanioides and Phragmitiesaustralis on $\mathrm{Pb} / \mathrm{Zn}$ and $\mathrm{Cu}$ mine tailings amended with manure compost and sewage sludge: A study. Bioresour. Technol., 97, 158-170.

Dauda, S.N., Aliyu, L. \& Chiezey, U.F. (2005). Effect of seedling age at transplanting and poultry manure on fruit yield and nutrients of garden egg varieties. J. Trop. Sci., 5, 38-41.

Dauda, S.N., Ajayi, F.A. \& Ndor, E. (2008). Growth and yield of watermelon (Citrulluslanatus) as affected by poultry manure application. Journal of Agriculture \& Social Sciences, 121-124.

International Institute for Tropical Agriculture. (1979). Laboratory manual for soil and plant analysis. Ibadan: IITA. 
International Journal of Research in Agriculture, Biology \& Environment (ijagri), Vol. 2 (3), Jul-Sep - 2021

John, L.W., Jamer, D.B. Samuel, L.T. \& Warner, L.W. (2004). Soil Fertility and Fertilizers: An introduction to nutrient management. India: Pearson Education.

Khatik, S. K.\& Dikshi, P.R. (2001). Integrated use of organic materials and inorganic fertilizers on yield, quality, economics, and nutrition of sunflower grown in Haplustert clay soil. Ag. Sci. Digest., 21, 87-90.

Lai, Q.W., Li, C.G.\& Huang, Q.H. (1992). Effect of continuous application of inorganic fertilizer on soil structure properties of paddy soil derived from red soil. ActaPedologica Sinica, 29, 168-174.

Larney, F. J. \& Angers, D. A. (2012). The role of organic amendments in soil reclamation: A review. Can. J. Soil Sci., 92, 19-38.

Li, J.T.\& Zhang, B. (2007). Paddy soil stability and mechanical properties as affected by long-term application of chemical fertilizer and animal manure in subtropical China. Pedosphere, 17, 568-579.

Mokwunye, A. U., de Jager, A. \& Smaling, E. M. A. (1996). Restoring and maintaining the productivity of West Africa Soils: Key to sustainable development. Alabama: International Fertilizer Development Center.

Nelson, D. W. \&Sommers, L. S. (1982). Total carbon, organic carbon, and organic matter. Agron. Monogr. 9, 539-579.

Okoh, G. \& Hilson, G. (2011). Poverty and livelihood diversification: Exploring the linkages between smallholder farming and artisanal mining in rural Ghana. Journal of International Development, 23, 1100-1114.

Rodriguez, F., Guerrero, C., Moral, R., Ayguade, H. \& Mataix-Beneyto, J. (2005). Effects of composted and non-composted solid waste of pig slurry on nitrogen, phosphorus, and potassium contents into Mediterranean soils. Comm. Soil Sci. Plant Anal. $36,635-647$.

Sobulo, R. A. \& Babalola, O. (1992). Improved organic fertilizer and soil condition. Lagos: Federal Ministry of Agriculture, Water Resources and Rural Development.

Sullivan, D.M., Bary, A. I., Nartea, T.J., Myrhe, E.A., Cogger, C.G. \& Fransen, S.C. (2003). Nitrogen availability seven years after a high-rate food waste compost application. Compost Sci Util. 11, 265-273.

Wong, M. H. (2003). Ecological restoration of mine degraded soils, with emphasis on metal contaminated soils. Chemosphere, 50, $775-780$.

\section{Meshack Appiah Ofori}

College of Biology and the Environment

Nanjing Forestry University

Nanjing 2010037, PR China

*Corresponding author: appiahmeshack8@gmail.com 